\title{
The Idea of Democracy and the Ideology of the State: Pancasila Democracy in the Minds of Millennial's Voters
}

\author{
Maya Mustika Kartika Sari* \\ Pancasila and Civic Education Department \\ Faculty of Law and Social Sciences \\ Universitas Negeri Surabaya \\ Surabaya, Indonesia \\ mayamustika@unesa.ac.id
}

\author{
Rr. Nanik Seytowati \\ Pancasila and Civic Education Department \\ Faculty of Law and Social Sciences \\ Universitas Negeri Surabaya \\ Surabaya, East Java, Indonesia \\ naniksetyowati@unesa.ac.id
}

Warsono

Pancasila and Civic Education Department

Faculty of Law and Social Sciences

Universitas Negeri Surabaya

Surabaya, East Java, Indonesia

warsono@unesa.ac.id

\author{
Agus Satmoko Adi \\ Pancasila and Civic Education Department \\ Faculty of Law and Social Sciences \\ Universitas Negeri Surabaya \\ Surabaya, East Java, Indonesia \\ agussatmoko@unesa.ac.id
}

\begin{abstract}
The emergence of the phenomenon of antinationalism or neo-nationalism groups illustrates that the political community in Indonesia has difficulty in articulating political freedom within the framework of the Unitary State of the Republic of Indonesia. Democratization in the reform era is the beginning of political dynamics in Indonesia. The StateSociety interprets state democracy in a framework of thinking subjectively without referring to the nature of the existence of the Unitary State of the Republic of Indonesia. Pancasila democracy as the context of democracy in Indonesia has not become a reference for citizens in articulating the democratic process in Indonesia. If viewed from the process of internalizing the ideology of the state, the Pancasila education process and citizenship have a function of maintaining the values of the life of the state. The purpose of this study is to find out how millennial voters perceive Pancasila-based democracy,
\end{abstract} Voters

Keywords: Pancasila Ideology, Democracy, Millennial

\section{INTRODUCTION}

Political transformation in Indonesia has encouraged political restructuring, efforts to uphold human rights, and the growing freedom of individuals and mass media. The change was marked by the weakening of the state's hegemony towards the people and the strengthening of the people's involvement in politics. That is a phenomenon that developed in the reform era. Strengthening community involvement in politics encourages the presence of various group units in society. The shape, identity, size, and activity of each group variety. Some expressly declare themselves as political groups (political actors such as political parties, mass organizations, etc.), Some groups are oriented to social activities such as religious groups, women's activist groups, environmental activists, and others.
The variations in the strengthening of these community groups gave rise to dynamics in the process of democratization in Indonesia. This is reflected in the implementation of the General Elections and Regional Elections which are colored by various forms of euphoria of freedom to doubts about the generalization of democracy itself. Freedom of expression is represented by the rise of demonstrations, sometimes with anarchy.[1]Besides, various disputes related to the implementation of the elections, to the non-ethical political strategy that became the choice of politicians.

Research resultsshowing that democratizationin Indonesia which gives rise to the freedom of civil society in politics and participation in political, social, and religious associations, does not necessarily encourage an increase in the quality of public representation in political institutions to strengthen political integration[2],[3]This shows that the political community in Indonesia is experiencing difficulties in articulating political freedom within the framework of state collectivity. Citizens interpret democracy in a mindset subjectively without referring to Pancasila as the ideology of the Indonesian State. Subjective interpretations of democratic freedom give rise to new ideas that sometimes conflict with the ideology of Pancasila (the five foundations of the state).For this reason, it is important to understand how young/millennial voters view democracy in the context of the ideology of Pancasilaso that it can be seen as the political orientation of Indonesian nationality for the future.

Democracy and democratization require three conditions. [4]All three conditions are: (1) the existence of competition in power, (2) the participation of the people, and (3) the guarantee of civil and political rights. Democratic transition is the process of changing society from an old authoritarian socio-political structure to a new democratic social-political structure. The process of 
community change is always inseparable from the context (ie situation and condition) of society in a country. The process of change can be described as follows:

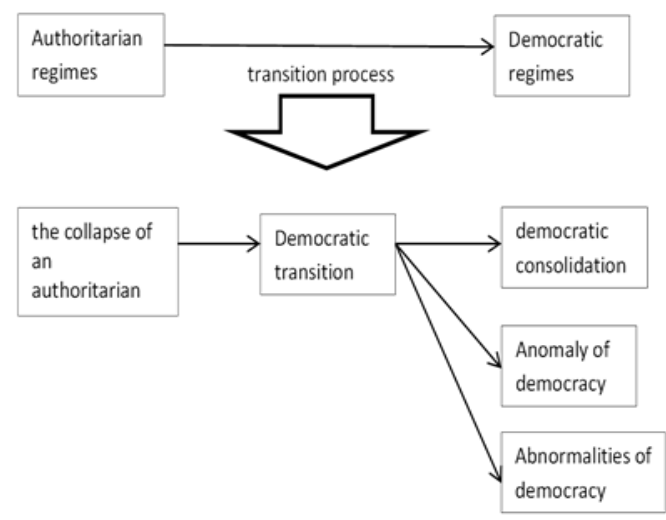

Figure 1Democratization Process

The democratic transition process is expected to lead to the consolidation of democracy, namely the emergence of new structures and processes that have stabilized and become the collective consciousness of the people, which in turn leads to the strengthening of democratic values in society. Democratic consolidation illustrates that the democratic process has developed positively. But if deviations occur in democratization then what happens is anomalous democracy or even abnormalities of democracy. Political anomaly is seen as a mismatch between what is desired and the political reality that occurs. One of them is the desire to maintain a presidential government system but tolerate a multi-party system. While the condition of abnormality is marked by the disruption of stability with the emergence of sharing ethnic riots, identity riots, corruption, and conflicts that do not reach consensus.[5]

Liberal political institutions are an absolute prerequisite for a state that calls itself a democratic state. Liberalization or democratization are two things that live and develop in society. Democracy cannot work only in the sector of political life, while other sectors of life are not democratic. Or liberalization cannot only apply in the economic field, while politics does not experience liberalization.[6]The basis of the concept of modern social democracy is the $1966 \mathrm{UN}$ basic rights convention, this document is a legal part of international rights. This document regulates and protects five human rights that must be possessed by humans, namely civil, political, social, economic, and cultural rights. The idea behind this is that the concept of human rights is a guarantee of the creation of opportunities for every individual citizen to gain freedom and personal development opportunities and to open up opportunities for individuals to participate fully in their social lives.[7]
So in the ideology of democracy, the responsiveness of the government to the preferences of its citizens politically equal must be the basis of their footing, the state must provide opportunities and opportunities for its citizens: (1) Formulate their preferences, (2) Show their preferences to citizens the state and government through personal and collective action and (3) give equal weight to their preferences, which are carried out by citizens. [8] When democracy is defined as competition, participation, and freedom, the process of democratization (change of the political system from non-democratic forms to more democratic forms) can be done in the two most essential ways, the road that is focused on competition and the way that is focused on participation.[9]

Increased participation (or inclusiveness) means an increase in the number of citizens who obtain political rights and freedoms. Non-democratic regimes might alienate most of their society from participation. In a democratic regime, all adult populations have the full right to freedom. Competition (or liberalization) involves the availability of rights and freedoms, at least for some members of the political system. Increased liberalization means increased opportunities for political opposition and increased competition for government power. The creation of an optimal democratic climate will have an impact on the strengthening of the rights of citizens to express their aspirations. Therefore, the study of citizens' preferences and references on democracy, democratization, and the conception of state life is something that needs to be done. It can project changes in state-society.

\section{METHOD}

This research is a qualitative descriptive study with several stages of the data collection process. The research subjects are a group of university students aged 19 to 20 years as many as 65 students. The stages of conducting research: (1) Individual interviews, (2) Focus group discussions to test data consistency, (3) In-depth interviews to strengthen information. The data is then analyzed quantitatively and qualitatively so that it can reveal comprehensive findings.

\section{RESULTS AND DISCUSSION}

A. General Description of Young Voters about Pancasila Democracy

The characteristics of young voters are millennial groups. Millennials have an extraordinary appeal in practical political events in Indonesia, even though the age range for millennials is still being debated. But no less 
important, they are not a shy generation, not obedient nor do they take a stand. Even these millennials have a firm attitude and do not hesitate to voice their political aspirations.Moreover, the era of the millennial is also supported by the presence of the natural resource bucket, especially in the technological aspect. Like laptops, the internet to smartphones. The millennial has several attitude tendencies, including surfing for seven hours a day, humbling and multitasking, which is doing two to three jobs at once.Also included in the issue of political tendencies, these millennials also have different attitudes between one another. Among them are those who are allergic to politics, politically literate, and signaling to intervene and engage in practical politics.

In terms of democracy and politics, millennials are the future of Indonesia's political and democratic civilizationin Indonesia. Millennials become the foundation of hope to realize a democracy that is responsive to the development of the world going forward. Millennial trends currently see the bad image of leaders, instead building their bad perceptions of political issues. These conditions will also impact for the fact that millennials are less concerned with political issues. This is inseparable from several factors, including differences in understanding, differences in character, regional differences and socioeconomic differences.

Young voters in viewing Pancasila Democracy are always confronted with the practice of democracy and governance in Indonesia today. Literacy sources that are used as a reference in exploring information are from the Internet. Based on the initial excavation orientation related to information sources about Pancasila Democracy are school / lecture books, Internet sources, information from other people (Teachers, Lecturers, Friends / Senior, Parents). Only a small fraction of the informants have the will to read sources of information derived from reference books or figures' thoughts.

General understanding of young voters about Pancasila democracy is oriented to the basic conception of democracy and Pancasila ideology. Pancasila democracy is understood and framed in a number of basic thoughts, namely: Pancasila democracy as a concept that departs from the universal conception of democracy that is applied in the context of Pancasila values. Pancasila Democracy is a system of government based on good and ideal leadership values, and Pancasila Democracy as a form of interaction / human relations that prioritizes deliberation and consensus in the conduct of shared life.

Based on the themes that emerged from the initial view of young voters, clarification of the research informants' opinions was related to the themes that had been raised. This shows the tendency of orientation and preference of young voters about Pamcasila democracy. Table 1 illustrates the views / perspectives of young voters on specific issues related to Pancasila democracy.

Table 1. Recapitulation of Opinion of Young Voters on Pancasila Democracy

\begin{tabular}{|c|c|c|c|c|c|}
\hline \multirow[b]{2}{*}{ No. } & \multirow{2}{*}{ STATEMENT } & \multicolumn{4}{|c|}{ YOUNG VOTER RESPONSE } \\
\hline & & Agree & $\%$ & $\begin{array}{c}\text { Not } \\
\text { Agree }\end{array}$ & $\%$ \\
\hline 1 & $\begin{array}{l}\text { Pancasila } \\
\text { democracy is a } \\
\text { system of } \\
\text { government that is } \\
\text { collective }\end{array}$ & 63 & 96.92 & 2 & 3.08 \\
\hline 2 & $\begin{array}{l}\text { In Pancasila } \\
\text { democracy, } \\
\text { electing a leader is } \\
\text { a civic duty }\end{array}$ & 61 & 93.85 & 4 & 6.15 \\
\hline 3 & $\begin{array}{l}\text { In Pancasila } \\
\text { democracy, there } \\
\text { is no coalition }\end{array}$ & 32 & 49.23 & 33 & 50.77 \\
\hline 4 & $\begin{array}{l}\text { In Pancasila } \\
\text { democracy, there } \\
\text { is no opposition }\end{array}$ & 28 & 43.08 & 37 & 56.92 \\
\hline 5 & $\begin{array}{l}\text { In Pancasila } \\
\text { democracy } \\
\text { individual } \\
\text { freedom is not } \\
\text { absolute }\end{array}$ & 47 & 72.31 & 18 & 27.69 \\
\hline 6 & $\begin{array}{l}\text { In Pancasila } \\
\text { democracy } \\
\text { decisions are made } \\
\text { according to the } \\
\text { will of the } \\
\text { majority }\end{array}$ & 35 & 53.85 & 30 & 46.15 \\
\hline 7 & $\begin{array}{l}\text { In Pancasila } \\
\text { democracy, } \\
\text { constitution is a } \\
\text { form } \\
\text { deliberation } \\
\text { agreement }\end{array}$ & 65 & 100.00 & 0 & 0.00 \\
\hline 8 & $\begin{array}{l}\text { In the ethics of } \\
\text { Pancasila } \\
\text { democracy the } \\
\text { people do not } \\
\text { criticize } \\
\text { government } \\
\text { directly }\end{array}$ & 43 & 66.15 & 22 & 33.85 \\
\hline
\end{tabular}

Table 1 data illustrates that there are things constructed in the same way and things that are constructed differently by young voters. The theme of Pancasila democracy which is constructed the same is (1) Pancasila democracy is oriented towards efforts to create an agreement through deliberation and this is manifested in the formulation of the 1945 Constitution of the Republic of Indonesia. (2) The system of government built within the Pancasila democracy framework is a collective government where there is a clear division of power between the executive, legislative, judiciary. (3) Choosing a leader in Pancasila democracy is an obligation for citizens.

The themes that are constructed differently and become a debate in focus group discussions are the opinions of young voters: (1) Individual freedom in Pancasila democracy is not 
an absolute thing. (2) Direct criticism is something that is less ethical Pancasila. (3) Majority decisions are not necessarily joint decisions. (4) Disclosure of coalition and opposition groups in the practice of Pancasila democracy.

From this problem, political education for the millennial is needed to build a culture of democracy in Indonesia. Political awareness is a psychological condition in giving attention to understanding a reality, so they are able to act and address the problems of state and development. There are several factors in political awareness. Among these include understanding, participation, preservation and maintaining the integrity of democracy. Inhibiting factors in the political awareness of young voters are the ever-changing organizational policies, autonomous novice voters, and the lack of support from the parent organization. The driving factors of political awareness for millennials are political stimuli, personal and social characteristics, political situation or environment and no less important is political education

The construction of young voters on Pancasila democracy leads to an adequate picture of an ideal democracy. Activities in organizations that are still minimal and the cultural influence of parents (traditional voter categories) make young voters not enough to be rational, critical, and objective political agents in determining their political attitudes and judgments. Educating voters to be rational is an absolute necessity for the continuation of democratization which is crawling in the shadow of past authoritarian rule. The reform agendas need to lead to the maturity of democracy. The people, especially young voters should be independent in determining political attitudes and are expected to simultaneously assess various political phenomena that occur.

Accelerated democratization in Indonesia still requires concrete efforts in implementing the concept of democracy. Understanding democratic values individually need to be elaborated in a structured way. Values that encourage competition, participation, and freedom need to be internalized at the individual level so that social order can be realized. The behavior of competition is not interpreted as the behavior of mutual cursing, blasphemy, and dropping, participation is not interpreted as a free will without limits. These three values must incarnate in the social behavior of the Indonesian people and are expected to build inthe social order.

The formation of civil society and social institutions is a dimension of democracy that must be strengthened. Democracy requires an independent civil society [9], a society that is aware of the formation of social order without resorting to violence. All problems that arise and are faced by the community must be resolved through dialogue and negotiation to find solutions without interference from state power through the hands of its officials. If this can be realized in Indonesia, people who have this type will become the controlling force for the government.

\section{CONCLUSIONS}

Based on the presentation of the results of the study it can be concluded that young voters view Pancasila democracy as a system of organizing the common good based on deliberation and consensus, but in practice, it leads to the following matters: (1) Pancasila Democracy Is Oriented on Collective Government Systems. (2) In Pancasila democracy, electing a leader is a civic duty. (3) In Pancasila democracy it is possible to have coalitions and opposition. (4) In Pancasila democracy individual freedom is not absolute. (6) In Pancasila democracy, decisions are made according to the common will. (7) In Pancasila democracy, a constitution is a form of deliberation. (8) Criticism of Ethical Government. Sugestion: a. Mobilizing young voters to aware and contribute in Democracy Practice in Indonesia; b. Government have the obligation to regulate pratical democary in Indonesia; c. Empowerment the knowledge Pancasila Democracy in all levels in society.

\section{REFERENCES}

[1] M. M. Edward Aspinall, "Southeast Asia's Troubling Elections: Nondemocratic Pluralism in Indonesia," J. Democr., vol. 30, no. 4, pp. 104-118, 2019.

[2] "Potret Demokrasi Di Indonesia."

[3] E. and M. M. Aspinall, Problems of Democratisationin Indonesia, Election, Institution and Society. Singapore: ISEAS, 2010.

[4] N. Chandoake, Neera, State and Civil Society: Exploration in Political Theory. London: Sage Publication, 2005.

[5] J. Snyder, "The Modernization Trap," J. Democr., vol. 28, no. 2, 2017.

[6] D. Held, Models of Democracy, Cambridge. Cambridge: Polity Press. 1987., 1987.

[7] G. Sorensen, Democracy and Democratization,Process and Prospect in a Changing World. Oxford: Westview Press Inc., 1993.

[8] B Macpherson. C., The Life and Times of Liberal Democracy. Oxford: University Press, 1997.

[9] F. Fukuyama, "Why National Identity Matters," $J$. Democr., vol. 29, no. 4, 2018. 